\title{
The Nature of the Potassium Compound Acting as a Promoter in Iron-Alumina Catalysts for Ammonia Synthesis
}

\author{
J. G. VAn OMmen, W. J. Bolink, ${ }^{1}$ J. Prasad ${ }^{2}$ \\ AND P. MARS \\ Twente University of Technology, Enschede, The Netherlands
}

Received February 7, 1974; revised October 21, 1974

\begin{abstract}
The chemical form of the potassium promoter on an iron-alumina catalyst during ammonia synthesis has been studied by two methods, viz, (i) the measurement of the equilibrium constant of the process $\mathrm{KNH}_{2}+\mathrm{H}_{2} \rightleftharpoons \mathrm{KH}+\mathrm{NH}_{3}$, and (ii) chemical analysis of the used catalyst. The equilibrium constant measurements gave $K_{723}=(12.9 \pm 0.5) \times 10^{-3}$, $\Delta H_{f_{298}}^{0}\left(\mathrm{KNH}_{2}\right)=-119 \pm 3 \mathrm{~kJ} \mathrm{~mol}^{-1}$ and $S_{248}^{0}\left(\mathrm{KNH}_{2}\right)=109 \pm 4 \mathrm{~J} \mathrm{~mol}^{-1} \mathrm{~K}^{-1}$. The chemical analysis showed that no $\mathrm{KNH}_{2}$ is present on the catalyst during synthesis. From these results and with the aid of thermodynamic considerations it is concluded that $\mathrm{KNH}_{2}, \mathrm{~K}$ and $\mathrm{K}_{2} \mathrm{O}$ are not stable compounds under conditions of ammonia synthesis. X-Ray diffraction showed that part of the potassium reacts with $\mathrm{Al}_{2} \mathrm{O}_{3}$, prohably leaving part of the potassium in the form of $\mathrm{KOH}$ which is quite stable under ammonia synthesis conditions.
\end{abstract}

\section{INTRODUCTION}

Potassium is a very important promoter in iron-alumina catalysts for ammonia synthesis $(1-6)$. The chemical state of the potassium promoter during ammonia synthesis and the mechanism by which potassium increases the rate of the ammonia synthesis have been the subjects of many hypotheses (4-11). Many authors suggested that potassium can be present as metal during ammonia synthesis $(8,12-18)$. This was a discussion point raised at the 5th International Congress on Catalysis after the paper by Ozaki et al. (1l). This suggestion that metal is present is supported by the fact that the first synthesis of potassium metal by reduction of potassium hydroxide was carried out with iron, although the conditions were different from those of the ammonia synthesis

\footnotetext{
${ }^{1}$ Present address: Laboratory for Pharmaceutical Technology, Groningen, The Netherlands.

${ }^{2}$ Present address: Indian Petrochemicals Corporation Limited, P.O. Jawaharnagar, Dist. Baroda, Gujarat, India.
}

(19-21). However, in the case that reduction to metal proceeds under ammonia synthesis conditions the metal will not be a stable phase because it has been reported that potassium metal will react quantitatively with ammonia gas at $350^{\circ} \mathrm{C}$ to potassium amide $(22,23)$. These two facts suggest that potassium may be present as an amide during ammonia synthesis. Besides this, also the formation of potassium hydride $(24,25)$ may be possible due to the establishment of the equilibrium:

$$
\mathrm{KNH}_{2}+\mathrm{H}_{2} \leftrightarrows \mathrm{KH}+\mathrm{NH}_{3}
$$

In our opinion there is no need at present for more speculation about the mechanism of the promoter action of potassium, because considerations about this point can only be fruitful when more information is available about the chemical nature of the potassium compound. The primary aim of this study was to investigate whether or not potassium amide is present in a conventional ammonia synthesis catalyst during ammonia synthesis as 
suggested before (see discussion after Ozaki et al. (11)). We accordingly determined the value of the equilibrium constant of the system (A) and we analyzed the composition of several catalysts, used in ammonia syntheses, by means of various methods.

\section{EXPERIMENTAL METHODS}

\section{Materials}

Catalyst 1 . An industrial catalyst consisting, in its unreduced form, of magnetite promoted with $3 \% \quad \mathrm{Al}_{2} \mathrm{O}_{3}, 0.45 \% \quad \mathrm{ZrO}_{2}$, $0.5 \% \mathrm{SiO}_{2}$ and $1.23 \%$ potassium. Particle size 2-3 $\mathrm{mm}$.

Catalyst 2. Catalyst 1 was impregnated with $8.3 \%$ potassium by soaking in an aqueous solution of $\mathrm{KOH}$ and evaporating the water. Particle size 2-3 mm.

Catalyst 3. $\alpha-\mathrm{Al}_{2} \mathrm{O}_{3}$ was soaked with solutions of $\mathrm{Fe}\left(\mathrm{NO}_{3}\right)_{3}$ and of $\mathrm{KOH}$. After evaporation of the water and drying at $110^{\circ} \mathrm{C}$, the catalyst contained $2 \%$ iron and $10 \%$ potassium. Particle size $2-3 \mathrm{~mm}$.

Catalyst 4 . This catalyst was prepared from a solution of $\mathrm{Fe}\left(\mathrm{NO}_{3}\right)_{3}$ and $\mathrm{Al}\left(\mathrm{NO}_{3}\right)_{3}$ by coprecipitation by addition of ammonia (26). The precipitate was dried $\left(75-110^{\circ} \mathrm{C}\right)$ and compressed to tablets $\left(6 \times 10^{8} \mathrm{~N}\right.$ $\mathrm{m}^{-2}$ ). Then the tablets were broken to a size between 2 and $3 \mathrm{~mm}$ and heated to $600^{\circ} \mathrm{C}$. The composition of the unreduced catalyst was $3 \% \quad \mathrm{Al}_{2} \mathrm{O}_{3}$ and $97 \% \quad \mathrm{Fe}_{2} \mathrm{O}_{3}$. Particle size 2-3 mm.

Catalyst 5. This catalyst was prepared by the same method as catalyst 4 and contained $1 \%$ potassium which was added in the same way as described for catalyst 2 . Particle size $0.3-0.7 \mathrm{~mm}$.

Chemicals were obtained as follows:

$\mathrm{KOH}$ from EKA-Bahn (Sweden), containing about $13.8 \% \quad \mathrm{H}_{2} \mathrm{O}$ and $0.6 \%$ $\mathrm{K}_{2} \mathrm{CO}_{3}$;

$\mathrm{K}$ (potassium metal) from Brocades (The Netherlands);

$\mathrm{Fe}\left(\mathrm{NO}_{3}\right)_{3} \cdot 9 \mathrm{H}_{2} \mathrm{O}$ p.a from Merck (Germany);
$\mathrm{Al}\left(\mathrm{NO}_{3}\right)_{3} \cdot 9 \mathrm{H}_{2} \mathrm{O}$ purum from Merck (Germany).

\section{Procedures}

\section{Purification of Nitrogen and}

\section{Hydrogen Used}

The nitrogen and hydrogen used in our experiments were purified in a train consisting of (a) a vessel containing $\mathrm{KOH}$ pellets for removal of carbon dioxide, (b) a converter filled with BTS copper catalyst for the removal of oxygen at $170^{\circ} \mathrm{C}$ and (c) a vessel filled with molecular sieve (Union Carbide type 13X) for the elimination of water and traces of carbon dioxide.

\section{Equilibrium Measurements}

Potassium amide was prepared in an autoclave of $500 \mathrm{cc}$ capacity (material Hastalloy c). Oxide-free potassium (7.8 g) was heated to $350^{\circ} \mathrm{C}$ in a stream of ammonia, dried over $\mathrm{KOH}$, until no further ammonia was taken up. According to Bergstrom and Fernelius (22) potassium amide formed rapidly and quantitatively via the reaction:

$$
\mathrm{K}+\mathrm{NH}_{3} \rightarrow \mathrm{KNH}_{2}+1 / 2 \mathrm{H}_{2} .
$$

Then the autoclave was cooled to room temperature in flowing ammonia gas.

The ammonia stream was stopped and hydrogen was fed into the autoclave up to a total pressure of $60 \times 10^{5} \mathrm{~N} \mathrm{~m}^{-2}$. The autoclave was heated to the desired temperature. At this temperature the system was kept at least for $16 \mathrm{hr}$, to reach equilibrium. The gas phase composition was determined by reducing the pressure in steps of $15 \times 10^{5} \mathrm{~N} \mathrm{~m}^{-2}$ and by absorption of the outcoming ammonia in a hydrogen chloride solution, followed by titration. After absorption of the $\mathrm{NH}_{3}$ the amount of hydrogen was determined by a gas meter.

The equilibrium constant,

$$
K_{A}=\frac{f_{\mathrm{NH}_{3}} \cdot x_{\mathrm{KH}}}{f_{\mathrm{H}_{2}} \cdot x_{\mathrm{KNH}_{2}}},
$$

( $f=$ fugacity; $x=$ mole fraction) was cal- 
culated from the amounts of ammonia and hydrogen withdrawn from the autoclave, the known amount of potassium used in the experiment and the pressure and the volume of the autoclave. For measuring the values of the equilibrium constant at a lower $\mathrm{KNH}_{2} / \mathrm{KH}$ ratio, the procedure described above was repeated after addition of a new amount of hydrogen. That equilibrium (A) really was established in the system was checked in two ways. The determination of the gas phase composition at $350^{\circ} \mathrm{C}$ over a period of $20 \mathrm{hr}$ showed that the composition did not change with time. Secondly, when the equilibrium temperature was reached from lower or higher temperatures, the gas phase composition was the same.

It was found that the gas phase composition was not a function of the pressure. This proves that potassium is not formed; moreover, the amount of ammonia formed was equivalent with the amount of hydrogen disappeared, the difference being less than $2 \%$.

The decomposition of ammonia could be neglected, because the total amount of $\mathrm{NH}_{3}$ withdrawn in the several stages from the autoclave was equivalent within $2 \%$ to the amount of potassium hydroxide titrated in the autoclave at the end of the experiment.

\section{Analysis of $\mathrm{NH}_{3}$ in the Catalysts \\ After Ammonia Synthesis}

The reduction of the catalysts and the ammonia synthesis were carried out in a modified version of the apparatus described by Bokhoven et al. (27). The modifications were as follows: (a) In the purification train instead of two vessels of activated alumina a vessel with silica gel was used, followed by one with molecular sieve 13X. (b) Instead of two reactors only one U-shaped reactor was used. The first leg of the reactor was filled with $6 \mathrm{~g}$ of catalyst 1 as a precatalyst. In the second leg catalyst 1, 2, 3 or 5 was present. For the blank (catalyst without $\mathrm{KOH}$ ) both legs were filled with catalyst 4 . We used the precatalyst to ensure that every catalyst to be tested came into contact with ammonia synthesis gas of near-equilibrium composition. (c) In the experiments with catalyst 2 also an extra prereactor was used, which contained $60 \mathrm{~g}$ of catalyst 1 . After reduction this catalyst was kept at room temperature to adsorb traces of water and oxygen which may pass the purification train.

Prior to use all catalysts were reduced during $30.5 \mathrm{hr}$ by raising the temperature slowly from 25 to $450^{\circ} \mathrm{C}$ in $10 \mathrm{hr}$; space velocity $=2 \times 10^{5} \mathrm{hr}^{-1}$. Meanwhile the gas composition was gradually increased from $0.5 \% \mathrm{H}_{2}$ (in $\mathrm{N}_{2}$ ) to $100 \% \mathrm{H}_{2}$. Reduction was continued for $20 \mathrm{hr}$ at $450^{\circ} \mathrm{C}$ and for $30 \mathrm{~min}$ at $500^{\circ} \mathrm{C}$. Then the rate of the reduction had decreased below $0.008 \%$ of the iron per hour and the reduction was stopped.

Ammonia synthesis took place at $100 \times 10^{5}$ or $200 \times 10^{5} \mathrm{~N} \mathrm{~m}^{-2}$ pressure with a $3: 1$ hydrogen-nitrogen mixture at $450^{\circ} \mathrm{C}$ and a space velocity of $2.5 \times 10^{4}$ $\mathrm{hr}^{-1}$ during $72 \mathrm{hr}$. The ammonia content in the offgas was always higher than 0.70 times the equilibrium content. Under a pressure of 100 or $200 \times 10^{5} \mathrm{~N} \mathrm{~m}^{-2}$ the reactor was cooled down in $16 \mathrm{hr}$ to room temperature. After release of the pressure the ammonia in the gas phase was driven out by means of a stream of nitrogen. Two procedures were used to analyze the amount of potassium amide and $\mathrm{NH}_{3}$ on the catalysts.

Procedure 1. A stream of hydrogen, wet nitrogen or hydrogen $\left(P_{\mathrm{H}_{2} \mathrm{O}} \sim 3 \times 10^{3} \mathrm{~N}\right.$ $\mathrm{m}^{-2}$ ) was passed through the bed, decomposing the $\mathrm{KNH}_{2}$ to $\mathrm{NH}_{3}$ and to $\mathrm{KH}$ or $\mathrm{KOH}$, respectively (22).

The temperature was increased from 25 to $500^{\circ} \mathrm{C}$ and this temperature was held until no further ammonia came out. Up to 
TABLE 1

The Mean Values of the Equilibrium CONSTANT $K_{A}$ as a FUNCTION OF

$r_{\text {KH }}$ AT $450^{\circ} \mathrm{C}$

\begin{tabular}{lrrrrrrrr}
\hline$x_{K H}$ & 0.1 & 0.2 & 0.3 & 0.4 & 0.5 & 0.55 & 0.6 & 0.7 \\
$10^{3} K .4$ & 12.8 & 13.0 & 12.9 & 14.0 & 14.5 & 17.3 & 22.3 & 22.4 \\
\hline
\end{tabular}

"Error with a $90 \%$ confidence level is: $0.5 \times 10 \%$

this temperature the ammonia decomposition rate in water-vapor-containing gas can be neglected. The ammonia formed was absorbed in hydrogen chloride solution and titrated.

Procedure 2. The catalyst was transferred into a conical flask under a stream of nitrogen gas. Distilled water was poured on the catalyst, decomposing $\mathrm{KNH}_{2}$. After addition of $\mathrm{KOH}$ the ammonia content was determined by distillation of the ammonia followed by titration. In both procedures the amount of $\mathrm{NH}_{3}$ found can be formed from $\mathrm{KNH}_{2}$ or can come from adsorbed $\mathrm{NH}_{3}$.

\section{RESULTS}

\section{The Equilibrium Constant $K$}

Table 1 shows the value of $K_{A}$ at $450^{\circ} \mathrm{C}$ as a function of the mole fraction $x_{\mathrm{KH}}$. Up to $x_{\mathrm{KH}}=0.5$ the values are practically constant.

Table 2 shows that the formation of

TABLE 2

The Mean Values of The EuUilibrium Constant $K_{A}$ at Different

TEMPERATURES ${ }^{a}$

\begin{tabular}{ccc}
\hline & $10^{3} K_{A}$ \\
Temp $\left({ }^{\circ} \mathrm{C}\right)$ & Measured & Calculated \\
& $9.0 \pm 1^{\circ}$ & 7.8 \\
250 & $9.2 \pm 1$ & 9.2 \\
300 & $10.1 \pm 1$ & 10.4 \\
350 & $12.9 \pm 0.5$ & 12.8 \\
450 & & \\
\hline
\end{tabular}

" $x_{K I I}<0.3$.

${ }^{b}$ Error with $90 \%$ confidence level.

c Calculated from $\Delta H_{468}^{0}=8 \mathrm{~kJ} \mathrm{~mol}^{-1}$ and $\Delta S_{\mathrm{AS}}^{0}=-26 \mathrm{~J} \mathrm{~mol}^{-1} \mathrm{~K}^{-1}$.
TABLE 3

amount of $\mathrm{NH}_{3}$ Determined on Catalysts After Ammonia Synthesis, By Means of Procedure $1^{a}$

\begin{tabular}{cccccc}
\hline $\begin{array}{c}\text { Expt } \\
\text { no. }\end{array}$ & Catalyst & $\begin{array}{c}\text { K content } \\
\text { (mmol) }\end{array}$ & $\begin{array}{c}\mathrm{NH}_{3} \\
(\mathrm{mmol})\end{array}$ & $\mathrm{NH}_{3} / \mathrm{K}$ & $\begin{array}{c}\text { Washing gas with } \\
3 \text { vol \% water vapor }\end{array}$ \\
\hline 5 & 1 & 3.77 & 1.34 & 0.35 & $\mathrm{H}_{2}$ \\
6 & 1 & 3.77 & 0.80 & 0.21 & $\mathrm{~N}_{2}$ \\
69 & 1 & 3.77 & 0.90 & 0.23 & $\mathrm{~N}_{2}+\mathrm{H}_{2}$ \\
7 & 1 & 3.77 & 0.33 & 0.08 & $\mathrm{~N}_{2}+\mathrm{H}_{2}{ }^{6}$ \\
10 & 4 & 0 & 1.04 & & $\mathrm{H}_{2}$ \\
11 & 4 & 0 & 0.68 & & $\mathrm{~N}_{2}$ \\
12 & 4 & 0 & 1.35 & & $\mathrm{H}_{2}$ \\
\hline
\end{tabular}

" $12 \mathrm{~g}$ catalyst. Ammonia synthesis took place at $p=100 \times 10^{5}$ $\mathrm{N} \mathrm{m}{ }^{-2}, T=450^{\circ} \mathrm{C}$

"Without 3 vol \% water vapor

$\mathrm{KNH}_{2}$ from $\mathrm{KH}$ and $\mathrm{NH}_{3}$ is favorable at all temperatures between 250 and $450^{\circ} \mathrm{C}$.

Analysis of the Ammonia

Content of Various

Catalysts After Ammonia

Synthesis

Table 3 shows that experiments according to procedure 1 do indicate a very small amount of $\mathrm{NH}_{3}$ which is hardly influenced by the presence of potassium. There is a large spread in the amount of ammonia determined.

The results obtained with procedure 2 (Table 4) also show that only a small fraction of the potassium can be present as $\mathrm{KNH}_{2}$. The amount of ammonia detected

TABLE 4

The Determination of $\mathrm{NH}_{3}$ ON Catalysts After Ammonia Synthesis by Means of Procedure $2^{\prime 2}$

\begin{tabular}{ccccc}
\hline Catalyst & $\begin{array}{c}\text { Wt of } \\
\text { catalyst } \\
(\mathrm{g})\end{array}$ & $\begin{array}{c}\mathrm{K} \text { content } \\
(\mathrm{mmol})\end{array}$ & $\begin{array}{c}\mathrm{NH}_{3} \\
(\mathrm{mmol})\end{array}$ & $\mathrm{NH}_{3} / \mathrm{K}$ \\
\hline 2 & 2.28 & 5.47 & 0.25 & 0.045 \\
3 & 5.7 & 14.57 & 0.21 & 0.015 \\
3 & 0.4 & 1.02 & 0.03 & 0.029 \\
$3^{b}$ & 4.9 & 12.53 & 0.16 & 0.013 \\
5 & 8.0 & 2.05 & 0.19 & 0.092 \\
\hline
\end{tabular}

a Ammonia synthesis took place at $p=100 \times 10^{5}$ $\mathrm{N} \mathrm{m}^{-2}, T=450^{\circ} \mathrm{C}$

${ }^{b} p-200 \times 10^{5} \mathrm{~N} \mathrm{~m}^{-2}$. 
per gram of catalyst is of the same order of magnitude as found by procedure 1 . It is also not influenced by the amount of potassium present in the catalyst.

\section{DISCUSSION}

\section{The Equilibrium $(A)$}

The results in Table 1 show that $K_{A}$ for $x_{\mathrm{KH}}<0.5$ is nearly constant, which means that the molten phase ( $\mathrm{KH}$ dissolved in $\mathrm{KNH}_{2}$ ) behaves ideally. At $x_{\mathrm{KH}}>0.5$ there is a deviation from ideality, perhaps due to the crystallization of $\mathrm{KH}(22,25)$.

From the values of $K_{A}$ we can conclude that in the melt mainly potassium amide will be present, provided the $\mathrm{NH}_{3} / \mathrm{H}_{2}$ ratio is not too low. Under ammonia synthesis conditions it is calculated that $x_{\mathrm{KNH}_{2}} \sim 17$ $x_{\mathrm{KH}}$ when $f_{\mathrm{NH}_{3}}=14.5 \times 10^{5} \mathrm{~N} \mathrm{~m}^{-2}, f_{\mathrm{H}_{2}}=70$ $\times 10^{5} \mathrm{~N} \mathrm{~m}^{-2}, T=450^{\circ} \mathrm{C}$. The potassium amide formed during ammonia synthesis will still be present after cooling the reactor to room temperature in the presence of $\mathrm{NH}_{3}-\mathbf{N}_{2}-\mathbf{H}_{2}$ equilibrium mixture, because the influence of temperature on $K_{A}$ is positive $\Delta H_{A}^{0}=8 \mathrm{~kJ} \mathrm{~mol}^{-1}$ ). This has been verified in a separate experiment, wherein the equilibrium constant was measured at $350^{\circ} \mathrm{C} ; \quad K_{A}=10^{-2}$ and after cooling $\left(50^{\circ} \mathrm{C} / \mathrm{hr}\right)$ to room temperature, $K_{A}=7 \times$ $10^{-3}$ was found. So by cooling to room temperature a little more amide will be formed.

\section{Thermodynamic Considerations on the Formation of $\mathrm{KNH}_{2}$ from $\mathrm{KOH}$}

From the 63 values of $K_{A}$, measured between 300 and $450^{\circ} \mathrm{C}$, with $x_{\mathrm{KH}}<0.3$, we calculated at the mean temperature of $375^{\circ} \mathrm{C}$ for reaction (A) $\Delta H_{648}^{0}=8 \pm 3 \mathrm{~kJ}$ $\mathrm{mol}^{-1}$ and $\Delta S_{648}^{0}=-26 \pm 4 \mathrm{~J} \mathrm{~mol}^{-1} \mathrm{~K}^{-1}$. [The values of $K_{A}$ at $250^{\circ} \mathrm{C}$ do not fit to a straight line in a $\ln K$ versus $T^{-1}$ plot, possibly due to crystallization of $\mathrm{KNH}_{2}$ (mp $335^{\circ} \mathrm{C}$ ).] From these values and $C_{p}$ values from literature $(28,29)$ with an estimated value of $C_{p}=70.0 \mathrm{~J} \mathrm{~mol}^{-1} \mathrm{~K}^{-1}$ for $\mathrm{KNH}_{2}$, we calculated $\Delta H_{298}^{0}=17.2 \mathrm{~kJ} \mathrm{~mol}^{-1}$ and $\Delta S_{298}^{0}=4.2 \mathrm{~J} \mathrm{~mol}^{-1} \mathrm{~K}^{-1}$. Now it is possible to calculate $\Delta H_{f_{298}}^{0}\left(\mathrm{KNH}_{2}\right)$ and $S_{298}^{0}$ $\left(\mathrm{KNH}_{2}\right)$ using the values given in the literature for $\mathrm{KH}(30), \mathrm{NH}_{3}(28,29)$ and $\mathrm{H}_{2}$ $(28,29)$. The results are:

$$
\begin{gathered}
\Delta H_{f_{298}}^{0}\left(\mathrm{KNH}_{2}\right)=-119 \pm 3 \mathrm{~kJ} \mathrm{~mol}^{-1} . \\
S_{298}^{0}\left(\mathrm{KNH}_{2}\right)=109 \pm 4 \mathrm{~J} \mathrm{~mol}^{-1} \mathrm{~K}^{-1} .
\end{gathered}
$$

The value of $\Delta H_{f_{28}}^{0}\left(\mathrm{KNH}_{2}\right)$ is better than to be expected in accordance with the literature value of $-118 \pm 2 \mathrm{~kJ} \mathrm{~mol}^{-1}$ (28). The value of $S_{298}^{0}\left(\mathrm{KNH}_{2}\right)$ was not found in the literature.

The interest in the thermodynamic data of $\mathrm{KNH}_{2}$ is based on the possible formation of $\mathrm{KNH}_{2}$ from $\mathrm{KOH}$ via the equilibrium:

$$
\mathrm{KOH}+\mathrm{NH}_{3} \leftrightarrows \mathrm{KNH}_{2}+\mathrm{H}_{2} \mathrm{O}
$$

This equilibrium is a crucial one for the formation of $\mathrm{KNH}_{2}$ on an ammonia synthesis catalyst. The constant of this equilibrium can be estimated by means of the values of $\Delta H_{f_{298}}^{0}$ and $S_{298}^{0}$ of $\mathrm{KOH}, \mathrm{NH}_{3}$ and $\mathrm{H}_{2} \mathrm{O}(28,29)$ in combination with the calculated values for $\mathrm{KNH}_{2}$. We found $K_{B}=$ $\left(10^{-7} \pm 0.4\right) \times 10^{-7}$ at a temperature of $450^{\circ} \mathrm{C}$. The actual value of $K_{B}$ may differ more than the error from the value given here. In the first place the thermodynamic values for $\mathrm{KNH}_{2}$ are not known with enough accuracy and also $S_{298}^{0}(\mathrm{KOH})$ is only an estimate (29). Secondly $K_{B}$ was calculated assuming that $\mathrm{KOH}$ and $\mathrm{KNH}_{2}$ form an ideal melt for every $x_{\mathrm{KNH}_{2}}(31)$. Thirdly it is known that it is very difficult to remove the last traces of water from $\mathrm{KOH}$ ( $31 \mathrm{a})$, so the actual equilibrium between $\mathrm{KOH} \cdot x \mathrm{H}_{2} \mathrm{O}$ and $\mathrm{KNH}_{2}\left(x_{\mathrm{H}_{2} \mathrm{O}} \ll\right.$ $0.5)$ can have an equilibrium constant which is considerably smaller than $K_{B}$ given above.

From the value of $K_{B}$ given above it can be concluded that the formation of potassium amide from potassium hydroxide is theoretically not favorable. It is, however, 
still possible, provided the $\mathrm{H}_{2} \mathrm{O} / \mathrm{NH}_{3}$ ratio is extremely small (below $3 \times 10^{-7}$ ).

\section{The Chemical Form of Potassium During Ammonia Synthesis}

\section{Potassium Amide}

The results in Table 3 show that the first method of ammonia detection gives a big spread in the values of ammonia determined on the catalyst. This is caused by the large surface area of the iron of the apparatus compared to the small amounts of ammonia detected. In order to obtain a more accurate determination we changed the method of detection and also increased the amount of potassium present on the catalyst (see Table 4). Both methods, however, give amounts of ammonia which are so small that they can be accounted for by absorbed ammonia (32) and/or nitrogen (33) on our catalyst which has a surface area of about $15 \mathrm{~m}^{2} \mathrm{~g}^{-1}$. This adsorbed nitrogen can form ammonia with hydrogen or water (33a). Indeed the amount of $\mathrm{NH}_{3}$ found in hydrogen was always larger than that in nitrogen. Moreover, they are not a function of the potassium content of the catalyst. From these arguments it can be concluded that no amide is formed during ammonia synthesis.

\section{Potassium and Potassium Hydride}

In accordance with the literature $(22,25)$ we observed that the reaction between ammonia and $\mathrm{K}$ or $\mathrm{KH}$ is fast at temperatures above $250^{\circ} \mathrm{C}$. From this fact and from the value of $K_{A}$ (see above) it follows that under $\mathrm{NH}_{3}$ synthesis conditions $\mathrm{KH}$ will be converted to $\mathrm{KNII}_{2}$. The same conclusion can be drawn for potassium metal on the basis of thermodynamic data $(28,29)\left(\Delta G_{723}^{0} \sim-22 \mathrm{~kJ} \mathrm{~mol}^{-1}\right)$. Therefore the conclusion that $\mathrm{KNH}_{2}$ is not present during $\mathrm{NH}_{3}$ synthesis implies the absence of both $\mathrm{KH}$ and $\mathrm{K}$ metal.

One could suggest that potassium may be stabilized by adsorption on the iron sur- face or by alloy formation with iron [see the discussion after Ozaki et al. (11)]. It can hardly be expected, however, that the adsorption of this species on iron is so strong in comparison with that of $\mathrm{KNH}_{2}$ that the latter cannot be present. It is also very unlikely that alloy formation between $\mathrm{K}$ and $\mathrm{Fe}$ will stabilize $\mathrm{K}$ metal because it is known (42) that at $943 \mathrm{~K}$ only $44 \mathrm{ppm}$ iron can be dissolved in liquid potassium and there is a decrease of solubility with decreasing temperature.

In accordance with these considerations, Ozaki et al. (35) obtained the indication by using a circulating gas system that the potassium metal used as a promoter was converted with the first amount of synthesized $\mathrm{NH}_{3}$ to $\mathrm{KNH}_{2}$.

\section{Potassium Oxide}

This compound may react with water to form $\mathrm{KOH}$ :

$$
1 / 2 \mathrm{~K}_{2} \mathrm{O}+1 / 2 \mathrm{H}_{2} \mathrm{O} \rightarrow \mathrm{KOH} .
$$

On the basis of thermodynamic data $(28,29)$ one can calculate that for this reaction $\Delta G_{723}^{0}=-84 \mathrm{~kJ} \mathrm{~mol}^{-1}$. This means that no appreciable amount of $\mathrm{K}_{2} \mathrm{O}$ is present if the water concentration is above about $10^{-2} \mathrm{ppm}$.

Moreover, $\mathrm{K}_{2} \mathrm{O}$ readily reacts with hydrogen into $\mathrm{KOH}$ and $\mathrm{KH}$ (34) or $\mathrm{K}$ (43) and further in $\mathrm{KNH}_{2}$, see above.

Therefore we must conclude that $\mathrm{K}_{2} \mathrm{O}$ cannot be present on the catalyst during ammonia synthesis.

\section{Potassium Hydroxide}

From the calculated equilibrium constant $K_{B}$ it follows that $\mathrm{KOH}$ gives $50 \%$ $\mathrm{KNH}_{2}$ (assuming that these compounds form an ideal mixture) provided that $p_{\mathrm{H}_{2} \mathrm{O}}=$ $10^{-7} p_{\mathrm{NH} 3}$. This means that when 20 vol\% $\mathrm{NH}_{3}$ is present in the outlet of an ammonia synthesis reactor, some $\mathrm{KOH}$ in the latter part of the reactor can be transformed into $\mathrm{KNH}_{2}$ provided the water vapor content of the gases is less than $0.02 \mathrm{ppm}$. Ob- 
viously our gas purity was not sufficient for this transformation to occur. (Analytical determination showed, however, that the water content was less than $1 \mathrm{ppm}$.)

In the primary reactor of a technical ammonia synthesis process the purity of the gas can hardly be expected to be better than in our experiments. Therefore it is very unlikely that under technical conditions potassium amide will be present. Moreover, the promoter action of potassium has been observed in the early days of the ammonia synthesis when gas purity was much lower than today. Therefore, the more general conclusion may be drawn that neither the presence of potassium amide nor that of potassium metal is essential for the promotion. It is very likely that potassium is present in the form of $\mathrm{KOH}$ during $\mathrm{NH}_{3}$ synthesis, while this is the most stable compound compared to $\mathrm{K}_{2} \mathrm{O}$, $\mathrm{K}, \mathrm{KH}$ or $\mathrm{KNH}_{2}$ in cases where traces of water vapor are present.

\section{Potassium Ferrites}

According to Egeubaev et al. (43) reduction with hydrogen decomposes this compound completely to iron. During the reduction at $500^{\circ} \mathrm{C}$ alkali is vaporized, mainly in the form of $\mathrm{KOH}$. The fact that no potassium is lost when compounds like $\mathrm{Al}_{2} \mathrm{O}_{3}$ or $\mathrm{SiO}_{2}$ are present points to a bonding of alkali to this type of promoter.

\section{Potassium Aluminates}

At $450^{\circ} \mathrm{C} \mathrm{KOH}$ is a liquid with a rather small but appreciable vapor pressure $(36,43)$. However, the $\mathrm{KOH}$ does not vaporize out of the ammonia synthesis reactor. This may be due to a rather strong adsorption on the iron surface and to a bonding with $\mathrm{Al}_{2} \mathrm{O}_{3}(4,6,36,37,43)$. Chen and Anderson (38) found with the aid of an electron probe microanalyzer that only a part of the $\mathrm{KOH}$ is bound to $\mathrm{\Lambda l}_{2} \mathrm{O}_{3}$, the rest being chemisorbed on the iron surface. The fact that $\mathrm{KOH}$ reacts with $\alpha-\mathrm{Al}_{2} \mathrm{O}_{3}$ under ammonia synthesis conditions is also supported by our observation that next to the diffraction pattern of $\alpha-\mathrm{Al}_{2} \mathrm{O}_{3}$ in catalyst 3 new lines appeared.

We are inclined to conclude that the explanation of the promoter action of potassium must be sought in the influence of $\mathrm{KOH}$ on the iron surface. According to several authors (39-4I) the presence of some potassium compound on the iron lowers the work function of iron. Thereby the iron could donate its electrons more easily to the reacting nitrogen (5, 9-11,39-41).

\section{CONCLUSIONS}

1. The results of the measurements of equilibrium $(\mathrm{A})$ in the temperature region $\left(300-450^{\circ} \mathrm{C}\right)$ provides the following data:

$$
\begin{aligned}
\Delta H_{j_{298}}^{0}\left(\mathrm{KNH}_{2}\right) & =-119 \pm 3 \mathrm{~kJ} \mathrm{~mol}^{-1} \\
S_{298}^{0}\left(\mathrm{KNH}_{2}\right) & =109 \pm 4 \mathrm{~J} \mathrm{~mol}^{-1} \mathrm{~K}^{-1}
\end{aligned}
$$

2. Experiments show that no $\mathrm{KNH}_{2}$ is formed on an ammonia synthesis catalyst under the conditions of $\mathrm{NH}_{3}$ synthesis.

3. By means of thermodynamic considerations and from what is known from the literature it is concluded that under normal ammonia synthesis conditions potassium metal, $\mathrm{KH}, \mathrm{KNH}_{2}$ and $\mathrm{K}_{2} \mathrm{O}$ cannot be present in appreciable amounts.

4. The form of potassium on an ammonia synthesis catalyst is very probably $\mathrm{KOH}$, which partly reacts with $\mathrm{Al}_{2} \mathrm{O}_{3}$. From the fact that $\mathrm{KOH}$ is volatile at $450^{\circ} \mathrm{C}$ we must conclude that the interaction with the iron surface is rather strong.

\section{ACKNOWLEDGMENTS}

We thank P. van Berkel for his contribution in the experimental work, J. Sonnemans for his comments on the manuscript and J. M. Alberigs for technical assistance at the high pressure laboratory.

\section{REFERENCES}

I. Larson, A., and Brooks, A. D., Ind. Eng. Chem. 18, 1305 (1926).

2. Almquist, J. A., and Crittenden, E. D., Ind. Eng. Chem. 18, 1307 (1926).

3. Mittasch, A., in "Advances in Catalysis" (W. G. 
Frankenburg, V. I. Komarewsky and E. K. Rideal, Eds.), Vol. 2, p. 81. Academic Press, New York, 1950.

4. Nielsen, A., in "Advances in Catalysis" (W. G. Frankenburg, V. I. Komarewsky and E. K. Rideal, Eds.), Vol. 5, p. 1. Academic Press, New York, 1953.

5. Frankenburg, W. G., in "Catalysis" (P. H. Emmett, Ed.), Vol. 3, p. 171. Reinhold, New York, 1955.

6. Nielsen, A., in "An Investigation on Promoted Iron Catalysts for the Synthesis of Ammonia," 3rd ed. Julius Gjellerups Forlag, Copenhagen, 1968.

7. Krabetz, R., and Peters, A., Angew. Chem. 77, 333 (1965).

8. Scholten, J. J. F., J. Catal. 11, 280 (1968).

9. Aika, K., and Ozaki, A., J. Catal. 13, 232 (1969).

10. Nielsen, A., Catal. Rev. 4, 1 (1970).

11. Ozaki, A., Aika, K., and Morikawa, Y., Proc. 5th Intern. Congr. on Catal., 5th, 1972 2, 1251 (1973).

12. Kunsman, C. H., Science 62, 269 (1925).

13. Kunsman, C. H., J. Phys. Chem. 30, 525 (1926).

14. Kunsman, C. H., J. Franklin Inst. 203, 635 (1927).

15. Brewer, A. K., J. Amer. Chem. Soc. 53, 83 (1931).

16. Brewer, L., and Mastick, P. F., J. Amer. Chem. Soc. 73, 2045 (1951).

17. Ref. (4), p. 17.

18. Ref. (5), p. 240.

19. Guy-I.ussac, I.. J., and Thenard, L. J., J. Ann. Chim. 65, 325 (1808).

20. Hackspill, L., and Grandadam, R., C. R. Acad. Sci. 180, 69 (1925).

21. Hackspill, L., and Grandadam, R., Ann. Chim. 5, 217 (1926).

22. Bergstrom, F. W., and Fcrnclius, W. C., Chem. Rev. 12, 43 (1933).

23. Dennis, L. M., and Browne, A. W., in "Inorganic Synthesis" (H. S. Booth, Ed.), Vol. 1, p. 74. McGraw-Hill, New York, 1953.

24. Moisson, H., C. R. Acad. Sci. 134, 18 (1902).

25. Guntz, A., and Benoit, F., Bull. Soc. Chim. 41, 434 (1927).

26. Rubinstein, A. M., Prilytkova, N. A., Akimov, V. M., Klyachko-Gurvich, A. L.. Slinkin,
A. A., and Mel'nikova, I. K., Kinet. Katal. 6, 285 (1965), Engl. transl. p. 243.

27. Bokhoven, C., Gorgels, M. J., and Mars, P., Trans. Faraday Soc. 55, 317 (1959).

28. Rossini, F. D., Wagman, D. D., Evans, W. H., Levini, S., and Joffe, J., in "Selected Values of Chemical Thermodynamic Properties." 2nd ed., Parts 1 and 2, Nat. Bur. Stand. circ. 500, U.S. Govt. Printing Office, Washington, DC, 1961.

29. Karapet'yants, M. K. H., and Karapet'yants, M. L., in "Thermodynamic Constants of Inorganic Compounds." Humphrey Science, London, 1970.

30. Herold, M. A., C. R. Acad. Sci. 224, 1826 (1947).

31. Lumsden, J., in "Thermodynamics of Molten Salt Mixtures." Academic Press, New York, 1966.

31a. Rollet, R., Cohen-Adat, J., Chouchron, U., Bull. Soc. Chim. 1959, 146.

32. Amenomiya, Y., and Pleizier, G., J. Catal. 29, 319 (1973).

33. Scholten, J. J. F., thesis, Technical Univ. Delft, 1959.

33a. Emmett, P. H., and Brunauer, S., J. Amer. Chem. Soc. 56, 35 (1934).

34. Rengade, E., C. R. Acad. Sci. 144, 754 (1907).

35. Aika, K., Hori, H., and Ozaki, A., J. Catal. 27, 424 (1972)

36. Emmett, P. H., and Brunauer, S., J. Amer. Chem. Soc. 54, 310, (1937).

37. Brunauer, S., and Emmett, P. H., J. Amer. Chem. Soc. 62, 1732 (1940).

38. Chen, H., and Anderson, R. B., J. Catal. 28, 161 (1973).

39. Boudart, M., J. Amer. Chem. Soc. 74, 3556 (1952).

40. Ivanov, M. M., Rudnitzkii, L. A., Ravina, P. D., and Kuznetsov, L. D., Kinet. Katal. 9, 1239 (1968), Engl. transl. p. 1018.

41. Rudnitzkii, L. A., and Berengarten, M. G., Kinet. Katal. 13, 115 (1972), Engl. transl. p. 98.

42. Shunk, E. A., in "Constitution of Binary Alloys," Sec. Suppl., p. 331. McGraw-Hill, New York, 1969.

43. Egeubaev, S. K., Rogozhina, S. A., Kuznetsov, D. A., and Zubova, I. E., Kinet. Katal. 6, 754 (1965), Engl. transl. p. 676. 